\title{
ОСОБЛИВОСТІ ВИЗНАЧЕННЯ КІНЕМАТИЧНИХ ХАРАКТЕРИСТИК РАМНО-ТРАПЕЦЕЇДАЛЬНОГО СТРУМОЗНІМАЛЬНОГО ПРИСТРОЮ
}

\author{
Представив д-р техн. наук, професор О.В. Устенко
}

Вступ. На сьогодні частка робіт на залізничному транспорті, що виконується електричною тягою, перевищує 80 \%. При цьому електротяговий рухомий склад (ЕTPC), який задіяний при здійсненні пасажиро- та вантажоперевезень в більшості експлуатується у наднормативний термін. Разом 3 тим, державними програмами оновлення рухомого складу передбачено розроблення та введення в експлуатацію нових електровозів підвищеної швидкості вітчизняного виробництва. При цьому особливу увагу слід приділяти струмознімальним пристроям (СЗП), які відповідають за безперебійну та надійну роботу ЕТРС.

Аналіз останніх досліджень та публікацій. Конструкції існуючих СЗП відрізняються складністю побудови, містять просторові ланцюги, які мають велику кількість ланок та з'єднань. Тому в Українській державній академії залізничного транспорту під керівництвом д.т.н., професора В.I. Мороза була розроблена нова рамно-трапецеїдальна конструкція механічної системи (МС) СЗП, яка відрізняється від існуючих меншою кількістю рухомих ланок та з'єднань, зменшеною приведеною до верхнього вузла сили тертя всіх шарнірів та збільшеною жорсткістю в поздовжньому та поперечному напрямках $[1,2]$.

Одним 3 основних показників якісної роботи СЗП є контактне натискання, для визначення якого необхідно проводити комплекс кінематичних досліджень. При цьому аналіз науково-технічної літератури і конструкторської документації засвідчив, що важільні механізми існуючих $\mathrm{i}$ створюваних перспективних СЗП являють собою просторові кінематичні ланцюги, ланки яких утворюють нижчі кінематичні пари. В той же час при розрахунках їх кінематики зазвичай застосовуються орієнтовані на використання для плоских кінематичних ланцюгів геометричні методи [3], що приводить до появи суттєвих похибок в результатах досліджень. Це обгрунтовує необхідність розроблення i використання нових підходів до уточненого математичного моделювання кінематичних характеристик просторових механізмів СЗП, що відіграє важливу роль в розрахунках їх динамічних характеристик.

Метою статі с висвітлення особливостей розрахунку швидкостей та прискорень рухомих ланок нового рамнотрапецеїдального СЗП.

Визначення параметрів трапецеїдального струмознімального пристрою. Основу нового підходу складає метод перетворення координат [4], застосування якого для просторових кінематичних ланцюгів СЗП з визначеною структурою передбачає матричний запис рівнянь координат шуканих положень точок відповідних ланок.

Загальні формули перетворення координат для систем $X_{i} Y_{i} Z_{i}$ i $X_{j} Y_{j} Z_{j}$ мають такий вигляд: 


$$
\begin{aligned}
& X_{i}=k_{11} \cdot X_{j}+k_{12} \cdot Y_{j}+k_{13} \cdot Z_{j}+A_{i} \\
& Y_{i}=k_{21} \cdot X_{j}+k_{22} \cdot Y_{j}+k_{23} \cdot Z_{j}+B_{i} \\
& Z_{i}=k_{31} \cdot X_{j}+k_{32} \cdot Y_{j}+k_{33} \cdot Z_{j}+C_{i}
\end{aligned}
$$

де $A_{i}, B_{i}, C_{i}$ - координати початку системи $X_{j} Y_{j} Z_{j}$ в системі $X_{i} Y_{i} Z_{i}$;

$k_{11}, k_{12}, \ldots k_{33}-$ коефіціснти при координатах - напрямні косинуси

$$
\begin{array}{rrr}
k_{11}=\cos \left(X_{i}^{\wedge} \mathrm{X}_{\mathrm{j}}\right) ; & k_{12}=\cos \left(X_{i}^{\wedge} \mathrm{Y}_{\mathrm{j}}\right) ; & k_{13}=\cos \left(X_{i}^{\wedge} \mathrm{Z}_{\mathrm{j}}\right) ; \\
k_{21}=\cos \left(Y_{i}^{\wedge} \mathrm{X}_{\mathrm{j}}\right) ; & k_{22}=\cos \left(Y_{i}^{\wedge} \mathrm{Y}_{\mathrm{j}}\right) ; & k_{23}=\cos \left(Y_{i}^{\wedge} \mathrm{Z}_{\mathrm{j}}\right) ; \\
k_{31}=\cos \left(Z_{i}^{\wedge} \mathrm{X}_{\mathrm{j}}\right) ; & k_{32}=\cos \left(Z_{i}^{\wedge} \mathrm{Y}_{\mathrm{j}}\right) ; & k_{33}=\cos \left(Z_{i}^{\wedge} Z_{\mathrm{j}}\right) .
\end{array}
$$

Запис рівняння (1) у матричній формі буде мати вигляд

$$
\begin{gathered}
r_{i}=T_{j i} \cdot r_{j}, \\
r_{i}=\left\|\begin{array}{c}
X_{i} \\
Y_{i} \\
Z_{i} \\
1
\end{array}\right\|, \quad r_{j}=\left\|\begin{array}{c}
X_{j} \\
Y_{j} \\
Z_{j} \\
1
\end{array}\right\|, \quad T_{j i}=\left\|\begin{array}{cccc}
k_{11} & k_{12} & k_{13} & A_{i} \\
k_{21} & k_{22} & k_{23} & B_{i} \\
k_{31} & k_{32} & k_{33} & C_{i} \\
0 & 0 & 0 & 1
\end{array}\right\| .
\end{gathered}
$$

Матриця коефіцієнтів рівнянь (1) отримується з урахуванням відомих формул зв'язків між напрямними косинусами і кутами Ейлера [4]

$$
T_{j i}=\left\|\begin{array}{llll}
\cos \psi_{j i} \cdot \cos \varphi_{j i}- & -\cos \psi_{j i} \cdot \sin \varphi_{j i}- & \sin \theta_{j i} \cdot \sin \psi_{j i} & A_{i} \\
-\cos \theta_{j i} \cdot \sin \psi_{j i} \cdot \sin \varphi_{j i} & -\cos \theta_{j i} \cdot \sin \psi_{j i} \cdot \cos \varphi_{j i} & \\
\sin \psi_{j i} \cdot \cos \varphi_{j i}+ & -\sin \psi_{j i} \cdot \sin \varphi_{j i}+ & -\sin \theta_{j i} \cdot \cos \psi_{j i} & B_{i} \\
+\cos \theta_{j i} \cdot \cos \psi_{j i} \cdot \sin \varphi_{j i} & +\cos \theta_{j i} \cdot \cos \psi_{j i} \cdot \cos \varphi_{j i} & \\
\sin \theta_{j i} \cdot \sin \varphi_{j i} & \sin \theta_{j i} \cdot \cos \varphi_{j i} & \cos \theta_{j i} & C_{i}
\end{array}\right\| .
$$

Матриця (4) в задачах теорії механізмів i машин розглядається матрицею кінематичної пари і вважається базовою для запису матриць різних нижчих кінематичних пар.
На основі розробленого методу для механічної системи нового СЗП (рис. 1) було складено наведені нижче матриці

$$
r_{F 5}=T_{1-5} \cdot T_{3-1} \cdot r_{F 3},
$$




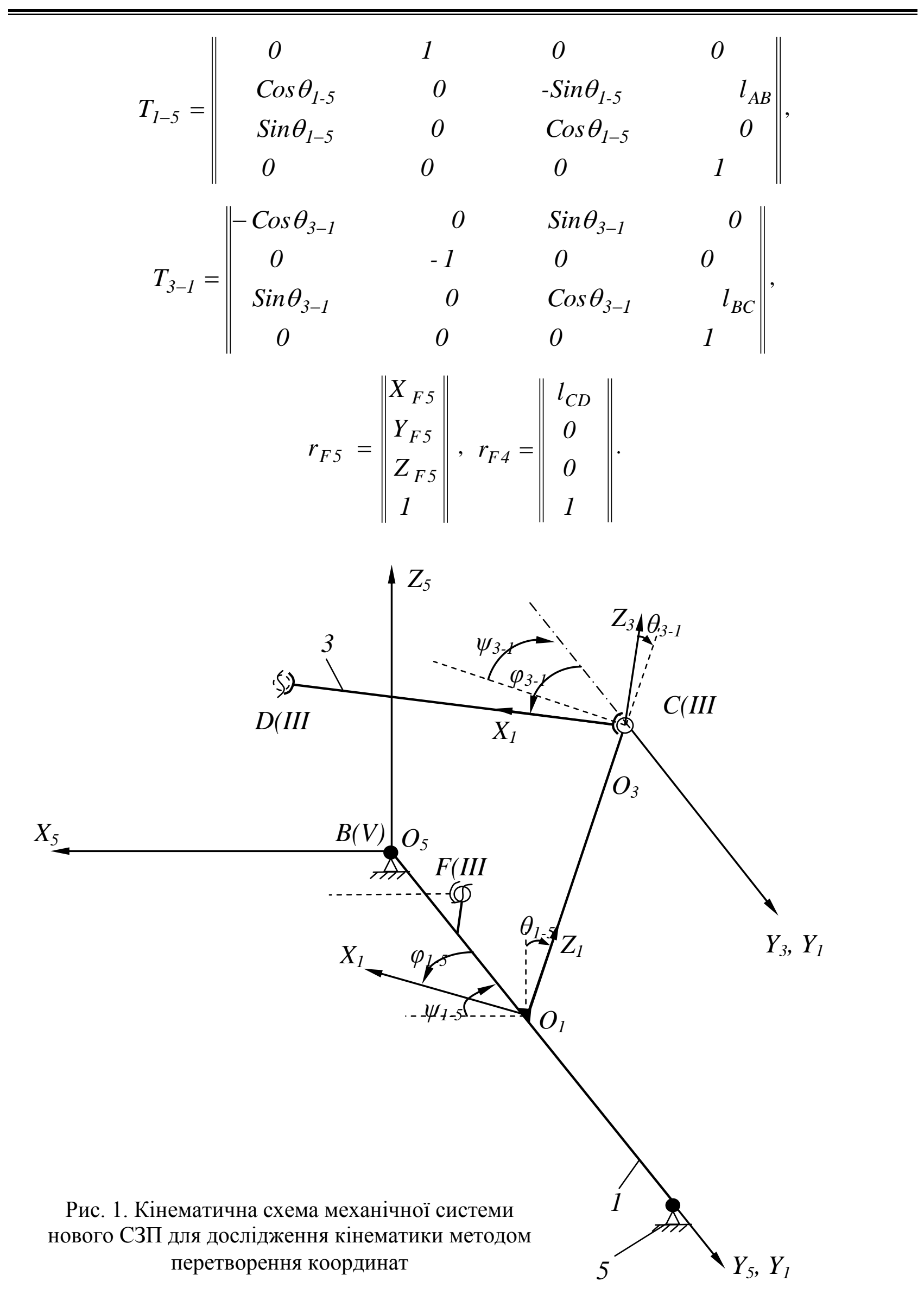


Проведені використанням MathCAD підтвердили працездатність запропонованої конструкції та дозволили визначити змінність прискорень ланок в залежності від робочої висоти СЗП (рис. 2).
Це має важливе значення при моделювані динамічних процесів у механічних системах СЗП, що в свою чергу дозволить робити уточнені оцінки рівнів контактних натискань при підвищених швидкостях pyxy ETPC.

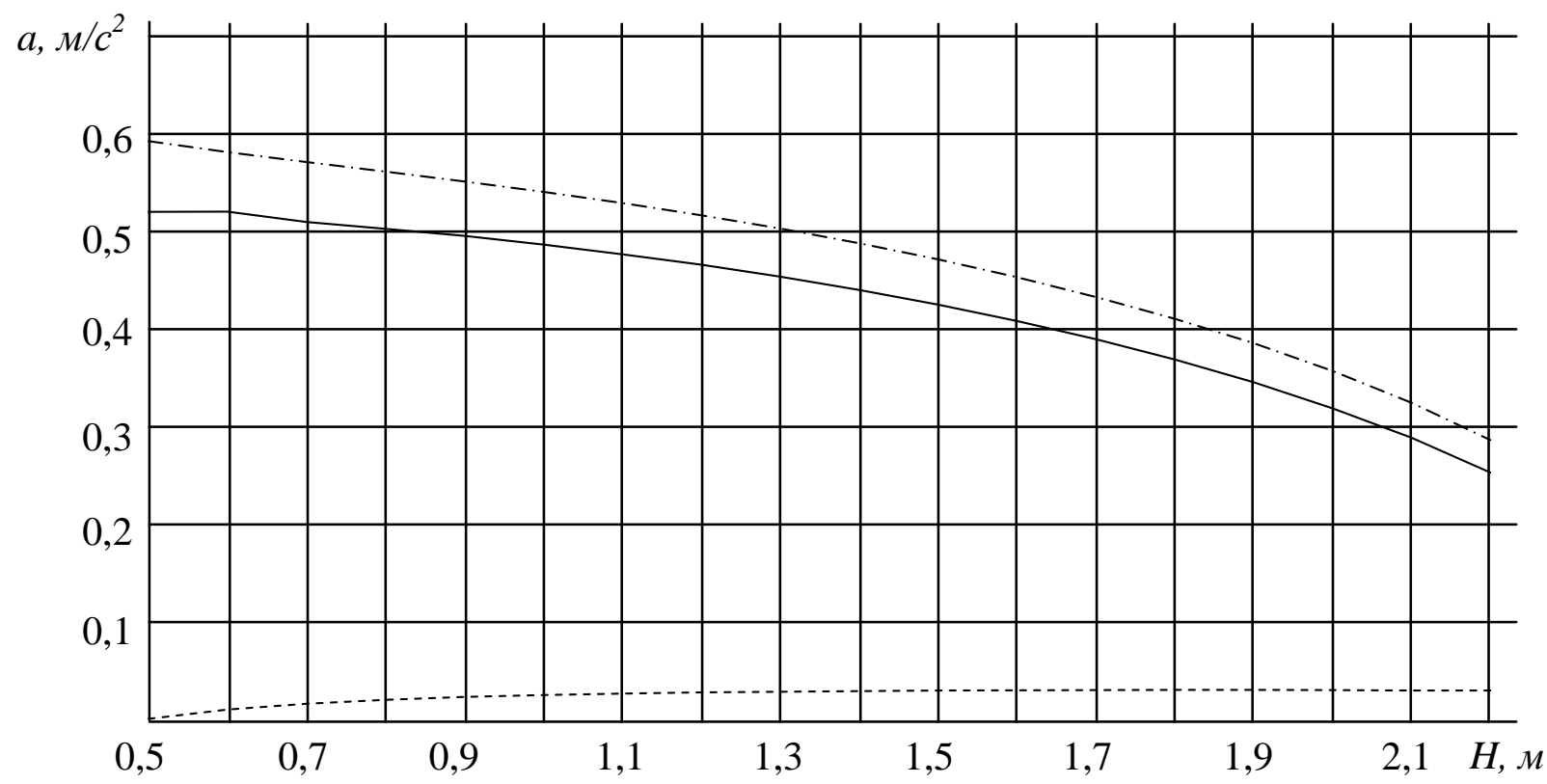

Рис. 2. Прискорення центру ваги ланок нового струмознімального пристрою при швидкості руху ЕТРС 200 км/год: ланка 2 ланка 1 ; ланка 3

Висновки i рекомендації щодо подальшого використання. Матеріали статті містять висвітлення особливостей визначення кінематичних характеристик просторової механічної системи нового рамно-трапецеїдального СЗП для ЕТРС підвищеної швидкості. Наведені розрахункові залежності забезпечують уточнене (y порівняні 3 плоскою кінематичною схемою) визначення кінематичних параметрів СЗП, що має важливе значення для математичного моделювання його динаміки i контролю контактних натискань при різних умовах експлуатації ЕТРС. Це також має важливе значення для визначення навантажень та контролю умов міцності деталей та з'єднань СЗП.

\section{Список літератури}

1. Струмознімний пристрій [Текст]: пат 85140 Україна: МПК В 60L5/00, B 60L5/18 / Мороз В.І., Братченко О.В., Павшенко А.В.; заявник та власник Українська державна академія залізничного транспорту. - № а 200706728; заявл. 15.06.07.; опубл. 25.12.2008, Бюл. № 24. -4 c. 
2. Мороз, В.І. Нова рамно-трапецеїдальна конструкція струмознімального пристрою для швидкісного електротягового рухомого складу [Текст] / В.І. Мороз, О.В. Братченко, А.В. Павшенко// Зб. наук. праць. - Харків: УкрДАЗТ. - 2008. - №. 96. - С. 24-30.

3. Беляев, И.А. Токосъем и токоприемники электроподвижного состава [Текст] / И.А. Беляев, В.П. Михеев, В.А. Шиян. - М.: Транспорт, 1976. - 184 с.

4. Левитский, Н.И. Теория механизмов и машин [Текст] / Н.И. Левитский. - М.: Наука, 1979. $-576 \mathrm{c}$.

Ключові слова: електротяговий рухомий склад, струмознімальний пристрій, механічна система, перетворення координат.

\section{Анотаціï}

Обгрунтовано актуальність проведення розрахункових досліджень 3 визначення кінематичних характеристик нового струмознімального пристрою рамно-трапецеїдальної конструкції для електротягового та моторвагонного рухомого складу підвищеної швидкості. Описано новий підхід дослідження кінематики рухомих ланок струмознімального пристрою, механічна система якого розглянута просторовою. Подані результати дослідження, які дозволяють проводити математичне моделювання динамічних процесів, що протікають в механізмі струмознімального пристрою.

Обоснована актуальность проведения расчетных исследований по определению кинематических характеристик нового токосъемного устройства рамно-трапецеидальной конструкции для электротягового та моторвагонного подвижного состава повышенной скорости. Описан новый подход исследования кинематики подвижных звеньев токосъемного устройства, механическая система которого рассмотрена пространственной. Представлены результаты исследования, которые позволяют проводить математическое моделирование динамических процессов, которые протекают в механизме токосъемного устройства.

Actuality of conducting of calculations researches is grounded on determination of kinematics descriptions of new currentremoval device of ramno-trapetseydal'noy construction for elektrotyagovogo and multiple-unit rolling stock raised to velocities. New approach of research of kinematics of mobile links of currentremoval device the mechanical system of which is considered spatial is described. Results are represented researches, which allow to conduct the mathematical design of dynamic processes which flow in the mechanism of currentremoval device. 